\title{
Implementasi Kota Layak Anak Melalui Program Sekolah Ramah Anak (SRA) di Kota Bekasi
}

\author{
Sarah Fitriya Anandasari ${ }^{1, *}$, Rahmat Hidayat ${ }^{1}$, Mochamad Faizal Rizki ${ }^{1}$ \\ ${ }^{1}$ Fakultas IImu Sosial IImu Politik; Universitas Singaperbangsa Karawang; Jl. H.S \\ Ronggowaluyo Telukjambe Timur Kabupaten Karawang, Jawa Barat, Indonesia; e-mail: \\ sfasari23@gmail.com, rahmah.hidayah74@yahoo.com, mochamad.faizal@fisip.unsika.ac.id \\ *Korespondensi: e-mail: sfasari23@gmail.com \\ Submitted: 10/10/2021; Revised: 18/11/2021; Accepted: 23/11/2021; Published: 31/12/2021
}

\begin{abstract}
High rates of abuse, whetever physcial, psycological or sexual, have come to the world's attention because it violates the rights of the child which also brought human rights to got protection. With the introduction of the new order, we have no need such things as life itself. Where the school going to be a student expression space. The study used a qualitative approach with a type of descriptive research that described how to city's child implemented process through a child-friendly school in Bekasi used three elements according to Ripley and Franklin. Policy result is realized the desired performance and impact.
\end{abstract}

Keywords: Child Friendly City, Child Violents, Child Protection, Child Friendly, Human Rights

\begin{abstract}
Abstrak
Tingginya angka kekerasan terhadap anak baik fisik, psikis ataupun seksual belakangan menjadi perhatian dunia sebab hal tersebut telah melanggar hak anak yang juga membawa hak asasi manusia untuk mendapatkan perlindungan. Berangkat dari hal tersebut, adanya kebijakan Kota Layak Anak, Indonesia Layak Anak bahkan Dunia Layak Anak bertujuan untuk meminimalisir dan menghilangkan kasus kekerasan terhadap anak dengan menghadirkan kota yang menunjang tumbuh kembang anak sebagai generasi penerus yang membutuhkan pembentukan karakter tanpa menggunakan kekerasan melalui sekolah ramah anak. Dimana sekolah akan menjadi ruang ekspresi anak sebagai peserta didik. Penelitian ini menggunakan pendekatan kualitatif dengen jenis penelitian deskriptif yang menggambarkan bagaimana proses implementasi kota layak anak melalui program sekolah ramah anak di Kota Bekasi menggunakan 3 elemen menurut Ripley dan Franklin. Kebijakan menghasilkan terwujudnya kinerja dan dampak yang diinginkan.
\end{abstract}

Kata kunci: Hak Asasi, Kekerasan Anak, Kota Layak Anak, Perlindungan Anak, Ramah Anak

\section{Pendahuluan}

Anak sebagai cikal bakal penggerak dan pemimpin yang akan sangat menentukan wujud kehidupan suatu bangsa di masa mendatang. Layaknya sebuah investasi bagi suatu negara, maka anak sudah sepatutnya mendapatkan perlindungan, pembentukan serta pengembangan bagi masing-masing individu sebab nantinya masa depan negara berada ditangan mereka, sebagai anak mudanya. Sehingga, apabila telah mempersiapkan pewaris bangsa yang berkualitas tentu akan berkorelasi dan berimplikasi terhadap bagaimana suatu negara di masa yang akan datang. 
Seseorang dapat dikategorikan sebagai anak dilihat dari batasan usia yang dimiliki. Menurut Kamus Besar Bahasa Indonesia, anak merupakan manusia kecil yang belum dewasa. Sedangkan, menurut Kitab Undang-Undang Hukum Perdata Pasal 330 menyatakan seseorang dengan usia tidak lebih dari 21 tahun dan tidak kawin masih digolongkan sebagai seorang anak (Subekti \& Tjitrosudibio, 2002). Anak sebagai makhluk kecil dan lemah, yang masih muda jiwa, usia dan perjalanan hidupnya sehingga keadaan sekitar mampu mempengaruhinya (Koesnan, 2005). Anak merupakan makhluk yang membutuhkan pemeliharaan, kasih sayang dan juga tenpat bagi perkembangannya baik fisik maupun mental (Monks et al., 2006)

Namun, anak menjadi hal yang belum mendapat atensi dari publik padahal banyak sekali permasalahan mengenai anak yang tidak kalah menggairahkan dengan dinamika politik di negeri ini. Munculnya stigma di masyarakat bahwa anak yang dimaksud hanya anak yang memiliki ikatan darah dengan mereka, dan cenderung pasif ketika berbicara mengenai anak, mengakibatkan tingginya angka kasus penculikan dan kekerasan terhadap anak. Bahkan tidak dipungkiri bahwa kekerasan terhadap anak kerap terjadi di lingkungan yang dekat dengan aktivitas anak itu sendiri.

Angka anak sebagai objek kekerasan cenderung masih tinggi sebab enam dari 10 anak didunia menjadi korban kekerasan meliputi kekerasan fisik, seksual dan psikologis baik dilingkungan rumah dan sekolah dimana seharusnya mereka mendapatkan keamanan (KPPA, 2007). Data yang diperoleh dari UNICEF yang merupakan badan organisasi khusus anak dibawah Perserikatan Bangsa-Bangsa menyebut bahwa dari 190 negara, hanya terdapat 39 negara yang benar-benar dapat menjamin dan melindungi anak dari kekerasan. Berawal dari hal tersebut, maka PBB mengesahkan Convention On The Rights of The Child atau Konvensi Hak-Hak Anak (KHA) pada tanggal 20 November 1989 yang berguna memberikan perlindungan serta menegakkan hak-hak anak. Sehingga, dengan adanya landasan hukum internasional yang bersifat memaksa tersebut, maka di setiap negara yang ada di dunia harus bebenah dan mulai memperhatikan anak-anak yang ada di dalam negaranya.

Maraknya kasus mengenai anak yang merupakan manifesto sebuah negara di masa depan disadari bahwa dibutuhkan penanganan serius dan berkelanjutan yang melibatkan seluruh instansi pemerintah dan masyarakat agar secara bersama-sama menekan kasus seperti itu. Sebab, anak merupakan tanggungjawab Negara Indonesia seperti yang tertuang dalam pembukaan Undang-Undang Dasar 1946 dalam alinea keempat poin pertama bahwa tujuan Negara Republik Indonesia salah satunya adalah melindungi segenap Bangsa Indonesia dan seluruh tumpah darah Indonesia. Indonesia telah meratifikasi CRC melalui Keputusan Presiden Nomor 26 Tahun 1990 dengan menekankan terhadap hak-hak anak sebagaiman berikut ; 1) Hak Atas Hidup, 2) Hak untuk tumbuh dan berkembang, 3) Hak untuk mendapatkan perlindungan, 4) Hak untuk berpartisipasi dalam hidup di masyarakat. Tetapi, tercatat di tahun 2006 angka kekerasan terhadap anak di level nasional menyentuh angka 3,02\% dengan proposisi 1,23 juta jiwa anak laki-laki sedangkan 1,06 juta jiwa anak perempuan (KPPA, 2007). Tentu saja hal ini bertentangan Undang-Undang Nomor 23 Tahun (2002) 
tentang Perlindungan Anak yang mana disebutkan dalam pasal 4 bahwa setiap anak berhak untuk dapat hidup, tumbuh, berkembang, berpartisipasi secara optimal sesuai dengan harkat dan martabat kemanusiaan, serta mendapat perlindungan dari kekerasan dan diskriminasi.

Untuk itu, pemerintah Indonesia mengeluarkan Undang-Undang Nomor 7 (2007) tentang Rencana Pembangunan Jangka Panjang Nasional yang terbagi dalam 5 tahap perencanaan pembangunan 5 tahunan, sehingga terbentuklah Undang-Undang Nomor 2 (2015) tentang Rencana Pembangunan Jangka Menengah Nasional 2015-2019 dimana dalam periodesasi 5 tahun tersebut, terdapat poin program melindungi anak, perempuan dan kaum marjinal yang menjadi salah satu dari sembilan agenda pembangunan jangka menengah nasional. Tentu saja, hal ini menjadi wujud keseriusan pemerintah dalam mengatasi permasalahan diatas. Program Indonesia Layak Anak (IDOLA) tahun 2030 menjadi jawaban atas keresahan tersebut.

Kota Layak Anak sebagai turunan guna mencapai Indonesia Layak Anak mulai dikembangkan di tahun 2006 dengan mengambil 5 daerah percontohan. Dan secara bertahap ke seluruh kabupaten atau kota yang ada di Indonesia. Pemerintah Indonesia melalui Kementrian Pemberdayaan Perempuan dan Perlindungan Anak menerbitkan Peraturan Menteri Pemberdayaan Perempuan Dan Pelindungan Anak Nomor 11 Tahun (2011) kebijakan Kabupaten/Kota Layak Anak. Sehingga dengan dibuatnya regulasi yang mengatur tentu memiliki kekuatan hukum yang memaksa sehingga produk tersebut harus diimplementasikan di seluruh wilayah Indonesia.

Program KLA menyasar kepada setiap kabupaten dan kota yang ada di Indonesia untuk bersama-sama memenuhi klaster agar daerah mendapat predikat layak anak. Selayaknya program nasional, secara otomatis pemerintah daerah tetap memiliki andil untuk merealisasikan apa yang menjadi keinginan pemerintah pusat. Sesuai dengan UndangUndang Nomor 23 Tahun (2014) tentang Pemerintahan Daerah dan diperkuat dengan Peraturan Pemerintah Republik Indonesia Nomor 18 Tahun 2016 (2016) tentang Perangkat Daerah bahwa urusan perlindungan anak menjadi urusan yang wajib ditangani oleh daerah sebagai ujung tombak perlindungan anak di daerah. Sebab, daerah memiliki hirarki yang lebih dekat dengan masyarakat yang merupakan kepanjangan tangan dari pemerintah pusat diharapkan mampu bertindak cepat dalam pemenuhan hak-hak terhadap anak dan menangani kasus-kasus yang melibatkan anak.

Kota Bekasi sebagai daerah yang secara geografis dekat dengan Jakarta sebagai Ibukota Negara Indonesia tentu harus bersiap dengan impact yang didapatkan sehingga harus bersifat adaptif dan menyelaraskan keinginan pemerintah pusat. Untuk itu, melalui Peraturan Daerah Kota Bekasi Nomor 13 Tahun (2017) tentang Kota Layak Anak sebagai bentuk komitmen Kota Bekasi sebagai salah satu daerah yang memperhatikan tumbuh kembang anak dan mencetak generasi yang berkarakter unggul berkualitas. Dalam menciptakan generasi berkarakter unggul dan berkualitas, tentu dilakukan oleh Dinas Pemberdayaan Perempuan dan Perlindungan Anak Kota Bekasi dengan pemenuhan terhadap salah satu dari lima kluster yang 
menjadi indikator suatu kota dikatakan sebagai layak anak yakni kluster keempat dibidang pendidikan, pemanfaatan waktu luang dan kegiatan budaya dengan menerapkan sekolah ramah anak.

Sekolah ramah anak hadir guna memperbaiki sistem yang sudah ada dalam pembentukan karakter anak sebagai peserta didik, karena dalam penerapan sekolah ramah anak tidak terdapat lagi sanksi yang menakutkan bagi anak, yang malah nantinya akan berimbas terhadap perilaku anak dimasa mendatang. Sehingga dengan adanya kebijakan tersebut, perlakuan dari setiap elemen di sekolah mampu lebih memanusiakan manusia sebab hukuman menggunakan kekerasan tidak akan pernah memberikan dampak baik di kemudian hari, karena sekolah ikut andil besar dalam membentuk karakter anak sebab hampir setengah waktu anak dihabiskan di sekolah.

Walaupun banyak artikel yang mengangkat kesamaan topik terkait kekerasan anak maupun Kota Layak Anak, tetap terdapat kebaharuan atau novelty melalui penelitian ini. Artikel berjudul "Kabupaten Kota Layak Anak" yang ditulis oleh Pattilima Hamid dari Universitas Indonesia menjelaskan kondisi ideal suatu Kabupaten atau Kota Layak Anak juga upaya untuk mewujudkannya (Hamid, 2017). Abdiana llosa dan Rusdi mengatakan dalam artikelnya yang berjudul "Analisis Pelaksanaan Program Kota Layak Anak (KLA) dalam Memenuhi Hak Sipil dan Kebebasan Anak di Kota Pekanbaru" bahwa masih belum maksimal penerapan KLA di Kota Pekanbaru terutama dalam klaster Hak Sipil dikarenakan beberapa faktor salah satunya adalah regulasi (Ilosa, 2020). Sedangkan keterbaruan dari artikel yang ditulis penulis menggambarkan keberhasilan atau success story dari Kota Bekasi dalam mengimplementasikan program Kota Layak Anak sehingga Kota Bekasi menempati Kota Layak Anak tingkat Nindya hanya dalam waktu empat tahun.

Berdasarkan uraian diatas, mendorong peneliti untuk melakukan penelitian dengan judul "Implementasi Kota Layak Anak melalui Sekolah Ramah Anak (SRA) di Kota Bekasi:"

\section{Metode Penelitian}

Penelitian ini menggunakan metode kualitatif deskriptif (Sugiono, 2016) dalam penelitian mengenai implementasi kota layak anak melalui program sekolah ramah anak di Kota Bekasi. Penggunaan metode ini diharapkan dapat mengidentifikasi permasalahan yang ada. Sehingga permasalahan kekerasan terhadap anak mampu diminimalisir. Informan yang dipilih menggunakan teknik Purposive Sampling (Sugiono, 2016) yaitu teknik pengambilan sumber data dengan pertimbangan tertentu. Salah satu kriteria dari informan adalah orang-orang yang dirasa mengerti mengenai program diatas, yakni lbu Ani selaku kepala seksi kesehatan dan kesejahteraan anak, Ibu Rita selaku Kepala Bidang Pemenuhan Hak Anak, Ibu Mimi selaku Kepala Seksi perlindungan hukum khusus anak, lbu Sagita sebagai staff bidang pengembangan hak anak, Ibu Indah sebagai Wakil Kepala Sekolah bidang Kemahasiswaan di SMK Negeri 6 Kota Bekasi, dan siswa-siswi yang terdampak dari adanya program ini. 
Kemudian dalam teknik pengumpulan data yang saya gunakan adalah wawancara, observasi dan dokumentasi.

Pemeriksaan terhadap keabsahan data dalam penelitian kualitatif pada dasarnya juga merupakan unsur yang tidak terpisahkan dari tubuh pengetahuan penelitian kualitatif (Moleong, 2008). Keabsahan data dilakukan untuk membuktikan apakah penelitian yang dilakukan benar-benar merupakan penelitian ilmiah sekaligus untuk menguji data yang diperoleh. Uji keabsahan data dalam penelitian kualitatif meliputi credibility, transferability, dependability, dan confirmability (Sugiono, 2016)

Agar data dalam penelitian kualitatif dapat dipertanggungjawabkan sebagai penelitian ilmiah perlu dilakukan uji keabsahan data. Adapun uji yang dilaksanakan dalam penelitian ini merupakan uji creadibilty/validitas internal dengan teknik pengecekan triangulasi, diantaranya triangulasi sumber, triangulasi teknik dan triangulasi waktu.

Triangulasi sumber digunakan peneliti untuk menguji kredibilitas data dengan cara mengecek data yang telah diperoleh melalui beberapa sumber. Data atau informasi digali dari Dinas Pemberdayaan Perempuan dan Perlindungan Anak Kota Bekasi, Pihak Sekolah di Kota Bekasi yang menerapkan Sekolah Ramah Anak (SRA) juga siswa-siswi sebagai sasaran kebijakan Sekolah Ramah Anak.

Triangulasi teknik digunakan peneliti untuk menguji kredibilitas data dengan cara mengecek data kepada sumber yang sama dengan teknik yang berbeda. Pengambilan data penelitian dilakukan dengan tiga macam teknik pengumpulan data, yakni wawancara, observasi, dan studi pustaka

Tringaluasi waktu, data yang dikumpulkan dengan teknik wawancara di pagi hari pada saat narasumber masih segar, akan memberikan data lebih valid sehingga lebih kredibel. Selanjutnya dapat dilakukan dengan pengecekan dengan wawancara, observasi atau teknik lain dalam waktu atau situasi yang berbeda.

\section{Hasil dan Pembahasan}

\subsection{Kota Layak Anak}

Kevin Lynch, artistik dari Massachusetts Intitute of Technology menemukan bahwa lingkungan kota yang terbaik untuk anak adalah yang mempunyai: komuniti yang kuat secara fisik dan sosial, komuniti yang mempunyai aturan jelas dan tegas, adanya pemberian kesempatan pada anak, dan fasilitas pendidikan yang memberikan kesempatan anak untuk mempelajari dan menyelidiki lingkungan dan dunia mereka (KLA, 2017).

Kota Layak Anak dijelaskan dalam Peraturan Menteri Pemberdayaan Perempuan Dan Pelindungan Anak Nomor 11 Tahun (2011) tentang Kebijakan Pengembangan Kabupaten/Kota Layak Anak sebagai kota atau kabupaten yang didalamnya mempunyai sistem pembangunan berbasis hak anak melalui pengintegrasian komitmen dan sumber daya pemerintah, masyarakat dan dunia usaha yang terencana secara menyeluruh dan berkelanjutan dalam kebijakan, program dan kegiatan yang menjamin terpenuhinya hak-hak 
anak. Peraturan tersebut menjelaskan bahwa dalam pemenuhan hak anak harus secara keseluruhan dimana setiap bidang saling mempengaruhi bagaimana wujud anak tersebut dimasa mendatang, jangan sampai terjadi hal-hal yang merugikan anak di masa depan karena hak anak sedari kecil belum mampu dipenuhi oleh negara.

Kota Layak Anak menurut UNICEF adalah kota yang memberikan jaminan kepada setiap anak mengenai perlindungan haknya sebagai warga kota, hak untuk mempengaruhi keputusan mengenai kotanya, hak berekspresi, hak untuk dapat berperan dalam lingkungan hidup bermasyarakat, hak untuk mendapatkan pelayanan dasar dibidang pendidikan dan kesehatan, hak mendapatkan air bersih dan akes terhadap sanitasi, hak terlindungi dari eksploitasi dan kekejaman, hak untuk bermain dengan temannya, hak untuk hidup dilingkungan bebas polusi, dan hak untuk mendapatkan akses setiap pelayanan dasar tanpa membedakan suku, bangsa agama, kekayaan, gender ataupun status penyandang disabilitas (Hamid, 2017).

Dari penjelasan diatas, secara jelas negara berkewajiban memberikan jaminan dan perlindungan terhadap anak, memberikan kebutuhan dasar anak sebagai komponen penunjang dalam pembentukan karakter yang diharapkan Bangsa Indonesia untuk generasi mudanya.

Sebagaimana ketika anak lahir telah membawa hak dasarnya sebagai manusia, untuk itu daerah berkewajiban memenuhinya sebagai bentuk realisasi Negara Indonesia dalam menghargai hak asasi manusia. Idealnya, setiap kota atau kabupaten harus memenuhi semua indikator yang telah ditetapkan dalam Konvensi Hak Anak (KHA) yang diklasifikasikan menjadi lima klaster pemenuhan hak anak sebagaimana yang tercantum dalam pasal 5 ayat 2, yaitu hak sipil dan kebebasan, lingkungan keluarga dan pengasuhan alternatif, kesehatan dasar dan kesejahteraan, pendidikan pemanfaatan waktu luang dan kegiatan budaya, perlindungan khusus.

Hak sipil dan kebebasan, meliputi hak atas identitas berupa kutipan akta kelahiran, hak untuk berekspresi dan mengeluarkan pendapat, hak berpartisipasi, berorganisasi dan hak untuk mendapatkan perlindungan kehidupan pribadi.

Lingkungan keluarga dan pengasuhan alternatif, meliputi bimbingan dan tanggungjawab orang tua yang mana harus adanya penguatan peran dan kapasitas orang tua dalam pembentukan karakter anak yang unggul berkualitas, reunifikasi, dukungan kesejahteraan bagi anak di segala bidang tanpa membedakan, penanganan lembaga pengasuhan alternatif.

Kesehatan dasar dan kesejahteraan, meliputi kesehatan dan layanan kesehatan serta jaminan sosial kesehatan dan standar hidup anak tanpa membedakan. Pendidikan, pemanfaatan waktu luang dan kegiatan budaya, meliputi akses terhadap pendidikan dan pelatihan yang berkualitas tanpa diskriminasi dan kekerasan, tujuan pendidikan guna mengembangkan minat dan bakat, menciptakan kehidupan yang toleran serta kegiatan liburan, kegiatan budaya dan olahrag dimana diberikan kesempatan bagi setiap anak untuk 
mendapatkan waktu beristirahat dan menggunakan waktu luangnya dengan kegiatan postif yang mereka sukai. Perlindungan khusus, meliputi penanganan terhadap korban kekerasan, ekploitasi, pornografi, human trafficking, korban konflik bersenjata, berhadapan dengan hukum, dan anak yang masuk kedalam kelompok minoritas adat.

Kota Bekasi yang telah mendeklarasikan diri sebagaai kota layak anak sejak tahun 2015 terus memperbaiki sistem sehingga tingkatan capaian Kota Bekasi sebagai Kota Layak Anak berada di tingkat Nindya. Ketika tahun 2015, mendapatkan peringkat pratama atau tingkat awal predikat capaian Kota Layak Anak. Tahun 2018 beranjak ke tingkat madya. Tahun 2019 memperoleh tingkat nindya. Masih terdapat tingkat utama kemudian baru predikat Kota Layak Anak. Dimana penilaian tersebut diadakan setiap tahun, dan harus ada perbedaan dengan sebelumnya.

\subsection{Sekolah Ramah Anak}

Sekolah Ramah Anak (SRA) adalah satuan pendidikan yang mampu menjamin, memenuhi, menghargai hak-hak anak dan perlindungan anak dari kekerasan, diskriminasi dan perlakuan salah lainnya serta mendukung partipasi anak terutama dalam perencanaan, kebijakan, pembelajaran dan mekanisme pengaduan. Sekolah Ramah Anak adalah sekolah yang secara sadar berupaya menjamin dan memenuhi hak-hak anak dalam setiap aspek kehidupan secara terencana dan bertangggungjawab.

Prinsip utama dalam penyelenggaraan SRA adalah kawasan sekolah yang penuh keramahan, non-deskriminatif, saling menghargai hak hidup serta penghargaan terhadap anak. (Undang-Undang Republik Indonesia Nomor 20 Tahun 2003) tentang Sistem Pendidikan Nasional Pasal 1 menjelaskan bahwa pemenuhan hak pendidikan anak adalah usaha sadar dan terencana untuk mewujudkan proses belajar dan proses pembelajaran agar peserta didik pada usia anak secara aktif mengembangkan dirinya untuk memiliki kekuatan spiritual keagamaan, pengendalian diri, kepribadian, kecerdasan, akhlak mulia, serta keterampilan yang diperlukan dirinya, masyarakat, bangsa dan negara.

Dalam pasal di atas, tentunya telah berkenaan dengan lima klaster dalam pemenuhan hak anak, di bidang hak sipil dan kebebasan, peserta didik berusia anak akan belajar berekspresi, berpendapat sebagai bentuk kebebasan bertanggungjawab mereka, sehingga terjadi pengembangan diri mereka dari yang masih malu berbicara di hadapan banyak orang menjadi lebih berani. Kemudian di bidang pendidikan, pemanfaatan waktu luang dan kegiatan budaya juga dapat ditemui di sekolah dengan tersedianya banyak aktivitas penunjang lainnya di luar kegiatan akademik, semisal kegiatan proyek sosial, pentas kesenian, pelatihan keterampilan, aksi pelestarian seperti pengolahan sampah sebagai salah satu rangka menumbuhkan kepekaan peserta didik terhadap lingkungan sekitar (Joga, 2019). Hal ini dirasa semakin diperlukan bagi generasi penerus bangsa sebab saat ini, anak-anak lebih menyukai bermain gadget dibandikan berbincang dengan teman sebaya mereka.

Lahirnya inisiasi mengenai sekolah yang ramah terhadap anak juga didasari bahwa banyaknya kasus yang menjadikan anak sebagai objek dari kekerasan baik fisik, verbal, 
ataupun seksual yang ada di sekolah. Berdasarkan data Komisi Perlindungan Anak Indonesia di tahun 2014-2015 terjadi kasus sebesar 30\% di lingkungan sekolah dengan guru sebagai pelaku teratas kekerasan (Davit Setiyawan, 2015) dengan bentuk pemberian hukuman tidak mendidik seperti mencubit diurutan atas sebanyak 504 kasus, disusul menjewer sebanyak 379 kasus dan membentak di posisi ketiga sebesar 357 kasus, adanya mindset dimana guru menjadi pihak yang selalu benar menyebabkan peserta didik berusia anak menjadi ciut untuk mengemukakan pandangan mereka mengenai apapun, padahal sejatinya bahwa lembaga pendidikan harus menjadi menjadi wadah ekspresi setiap anak.

Kemudian maraknya kasus bullying yang terjadi baik antara senior dengan junior maupun sesama teman sebaya menghantui anak sehingga merasa belum mendapatkan pengalaman bersekolah yang baik bagi memori anak tersebut. Data dari Komnas Perlindungan Anak Indonesia mencatat bahwa terjadi kenaikan di tiap tahunnya mengenai kasus anak sebagai korban ataupun pelaku bullying. Adapun data tersaji pada tabel 1.

Tabel 1. Jumlah Kasus Anak Sebagai Pelaku Atau Korban Bullying

\begin{tabular}{ccc}
\hline \multirow{2}{*}{ Kasus } & & \multicolumn{2}{c}{ Tahun } \\
\cline { 2 - 3 } & 2014 & 2015 \\
\hline Anak sebagai Korban Bullying & 159 orang & 147 orang \\
\hline Anak sebagai Pelaku Bullying & 67 orang & 79 orang
\end{tabular}

Sumber: Komnas Perlindungan Anak Indonesia (2015)

Hal ini tentu memprihatikan sebab akan berdampak ke masa depan apabila terus diabaikan. Berdasarkan pusat data dan informasi komnas PA yang mencatat bahwa di tahun 2015 sebanyak 62\% kejahatan terhadap anak terjadi di lingkungan terdekatnya seperti di rumah dan di sekolah (Putra, 2015).

Lalu adanya kasus anak sebagai korban ketidaklayakan bangunan sekolah karena banyak ditemukan sarana dan prasarana sekolah yang tidak sesuai dengan standar sehingga menciptakan kekhawatiran padahal seharusnya sekolah menjadi tempat yang aman bebas dari ancaman dan bahaya yang mengintai anak. Karena banyak hal tersebut, kehadiran SRA diharapkan dapat menjadi jawaban dan mengubah sistem secara perlahan namun berkelanjutan.

Pengaduan yang diterima komisi nasional perlindungan anak melalui surat, hotline service, layanan anak, layanan email, facebook dan media sosial lainnya sepanjang tahun 2015 terkait pelanggaran hak anak menyentuh angka 2.898 kasus dengan $59,30 \%$ merupakan kasus kejahatan seksual (Putra, 2015).

Sesuai dengan panduan sekolah ramah anak yang diterbitkan oleh Kementerian Pemberdayaan Perempuan dan Perlindungan Anak Republik Indonesia, sekolah ramah anak harus menganut enam komponen sebagai berikut: a) Adanya komitmen tertulis yang dapat dianggap sebagai kebijakan tentang sekolah ramah anak; b) Pelaksanaan proses pembelajaraan yang ramah terhadap anak; c) Pendidik dan tenaga kependidikan yang terlatih akan hak-hak setiap anak yang ada di area sekolah;d) Sarana dan prasarana yang raman 
terhadap anak; e) Partisipasi anak; f) Partisipasi orang tua, lembaga masyarakat, dunia usaha, pemangku kepentingan lain dan alumni.

Lebih jelas, Kota Bekasi melalui Peraturan Walikota Bekasi Nomor 25 Tahun 2016 tentang Sekolah Ramah Anak Kota Bekasi bahwa terdapat beberapa poin tambahan diluar panduan dari Kemeterian PP dan PA dalam indikator SRA untuk lembaga pendidikan di Kota Bekasi yang akan menjadi sekolah ramah anak. Seperti halnya dalam indikator pertama yakni kebijakan sekolah ramah anak (SRA) Kota Bekasi menambahkan komponen melalui peraturan walikota diatas yaitu SRA di Kota Bekasi untuk menghapuskan pungutan dalam penyelenggaraan pendidikan yang sudah didanai oleh APBN dan APBD. Sekolah ramah anak yang ada di Kota Bekasi juga proaktif mencegah adanya kasus putus sekolah peserta didik, serta memberikan $20 \%$ kuota pendidikan dari total daya tampung sekolah kepada anak dari keluarga kurang mampu. Kemudian dalam indikator kedua pelaksanaan kurikulum, dimana dalam Peraturan Walikota ditambah komponen bahwa sekolah yang ramah anak di Kota Bekasi wajib menyediakan ruang indoor dan outdoor untuk bermain dan belajar.

SRA yang ada di Kota Bekasi berdasarkan Surat Keputusan Kepala Cabang Dinas Pendidikan Wilayah III Provinsi Jawa Barat No. 421/356/CADISDIKWIL.III/2018 Tentang Penetapan Sekolah Ramah Anak Kota Bekasi untuk jenjang Sekolah Menengah Awal sebanyak 27 sekolah dari total sekolah tingkat menengah awal di Kota Bekasi sebanyak 113 sekolah, lalu untuk jenjang Sekolah Menengah Kejuruan hanya sebanyak 22 sekolah dari total 149 SMK di Kota Bekasi. Kemudian, untuk jenjang menengah pertama berdasarkan SK Kepala Dinas Pendidikan Kota Bekasi Nomor 188/1453-disdik.dikdas bahwa hanya sekitar 20 sekolah dari 285 sekolah yang berdiri di Kota Bekasi. Sedangkan untuk tingkat dasar hanya sebesar 18 sekolah dari total 653 sekolah. Dan untuk TK dan PAUD hanya sebesar 12 sekolah didasarkan pada Keputusan Kepala Dinas Pendidikan Kota Bekasi Nomor 421/584-disdik.paudpenmas tentang Sekolah Ramah Anak di Lingkungan Dinas Pendidikan Kota Bekasi.

\subsection{Implementasi SRA dalam Mewujudkan Kota Layak Anak di Kota Bekasi}

Implementasi menurut Ripley dan Franklin adalah apa yang terjadi setelah hukum tersebut disahkan sehingga seperti apa otoritasi program, kebijakan, manfaat atau jenis output lainnya yang nyata. Ini dimaksudkan terhadap serangkaian kegiatan yang mengikuti program dan hasil yang diinginkan oleh pejabat pemerintah. Implementasi disini meliputi aksi oleh beragam aktor yang dirancang untuk mewujudkan program. Jadi menurut Ripley dan Franklin bahwa implementasi berupa kegiatan atau tindakan nyata yang dilakukan setelah terbitnya aturan hukum yang mengatur mengenai suatu program yang ingin dicapai oleh pejabat pemerintah.

Keberhasilan suatu program dapat terimplementasikan atau tidak menurut Ripley dan Franklin dapat dilihat dengan tiga elemen berikut, yaitu kepatuhan, lancarnya runtinitas fungsi, terwujudnya kinerja dan dampak yang diinginkan. Sehingga dalam penelitian implementasi kebijakan kota layak anak melalui sekolah ramah anak di kota bekasi akann dikaji sesuai dengan teori dari Ripley dan Franklin. 
Kepatuhan, kesuksesan suatu program terimplementasikan dapat diukur melalui tingkat kepatuhan terhadap aturan hukum yang berlaku untuk program tersebut. Sebab, setiap program yang bergulir pasti memiliki landasan hokum yang menjadi dasar bergeraknya suatu program. Dengan kepatuhan maka kebijakan atau program tersebut dapat berjalan sesuai dengan yang seharusnya, dan menjadi unsur yang penting sebab aturan hukum menjadi orientasi dalam penerapan suatu kebijakan.

Dalam menerapkan Kota Layak Anak, Dinas PP dan PA Kota Bekasi telah merujuk kepada aturan yang dikeluarkan oleh Kementrian Pemberdayaan Perempuan dan Perlindungan Anak RI, dimana peraturan tersebut berisi kebijakan untuk menjadikan Indonesia Layak Anak, sehingga daerah wajib mengikutinya dengan membentuk program turunan yaitu Kota Layak Anak sesuai dengan Permen PP dan PA Republik Indonesia mengenai indikator suatu kota atau kabupaten dikatakan layak anak.

Dalam mewujudkan Kota Layak Anak, tentu DP3A Kota Bekasi tidak bekerja sendirian, Kota Layak Anak merupakan sistem terintegrasi dengan pemenuhan hak-hak anak dibidang lain. Maka dinas terkait seperti disdukcapil untuk urusan administrasi anak, disdikpora untuk urusan pendidikan, dinkes untuk urusan kesehatan dan lain sebagainya saling bahu membahu untuk mesukseskan Bekasi Layak Anak.

Sekolah ramah anak mulai digencarkan oleh DP3A bersama dengan Dinas Pendidikan, Pemuda dan Olahraga sejak walikota Bekasi mendeklarasikan diri sebagai Kota Layak Anak, melalui Peraturan Daerah, Peraturan Walikota Bekasi maka sekolah-sekolah yang berada di Kota Bekasi turut mendukung program nasional tersebut. Salah satunya SMK Negeri 6 Bekasi yang telah mendeklarasikan diri sejak 2016, setahun setelah Kota Bekasi berkomitmen menjadi ramah anak.

Hal ini terlihat dari keadaan lingkungan sekolah yang ramah anak, hampir $90 \%$ sekolah ini telah memenuhi komponen dalam indikator untuk menjadi sekolah ramah anak, salah satunya di sekolah ini telah terdapat ruang indoor dan outdoor yang mendukung tumbuh kembang anak untuk belajar dan bermain. Hal ini sesuai dengan peraturan tambahan oleh walikota bekasi melalui Peraturan Walikota Bekasi Nomor 25 tahun 2016. Kemudian adanya keserasian dengan dunia usaha, dimana Sekolah Menegah Kejuruan Negeri 6 Kota Bekasi menggandeng mitra elektronik yaitu SAMSUNG yang berperan sebagai pemberi akses terhadap peserta didik untuk karyawisata, praktik kerja lapangan (PKL) dan bahkan untuk kontrak kerja.

Sehingga untuk indikator kepatuhan, setiap instansi saling berpegang terhadap aturan hukum yang memanyungi sehingga pelaksanaannya tidak terlalu jauh berbeda dengan apa yang diharapkan oleh Pemerintah Indonesia. Kebijakan Kota Layak Anak melalui Sekolah Ramah baik lembaga pemerintah ataupun lembaga pendidikan sama-sama menjalankan program tersebut atas dasar aturan hukum yang berlaku, baik dari tingkat internasional, nasional maupun penguatan oleh aturan hukum daerah, yang mana aturan-aturan tersebut 
semuanya dijadikan dasar diberlakukannya suatu program oleh lembaga-lembaga terkait secara bertahap dan berkelanjutan.

Lancarnya rutinitas fungsi, keberhasilan program terlihat dari lancar tidaknya suatu instansi bergerak sesuai fungsinya. Jika semakin banyak hambatan yang menyebabkan tersendatnya rutinitas menjalankan fungsi otomatis suatu kebijakan belum berjalan dengan sebagaimana yang diharapkan.

Dalam hal ini, Dinas Pemberdayaan Perempuan dan Perlindungan Anak Kota Bekasi memiliki fungsi sebagai pelaksana dan pengawas di daerah. Pelaksana untuk penanganan kasus kekerasan anak di daerah, kemudian memberikan sosialisasi kepada setiap instansi yang ada di lingkungan Kota Bekasi, lalu masyarakat melalui kepala desa, camat, Ibu-ibu PKK di tiap kecamatan agar saling bersama-sama mensukseskan program KLA.

Sebagai pengawas, DP3A melakukan fungsi tersebut dalam menilai sejauh mana kemajuan komponen-komponen dalam melakukan perwujudan Kota Layak Anak, apabila masih ada yang kurang akan segera diperbaiki bersama dengan instansi terkait. Semisal, jika dicanangkan bulan ini ada dua puskesmas ramah anak, namun ternyata dilapangan hanya baru ada satu, maka akan dilakukan evaluasi dimana kekurangan dan hambatan. Dilakukan per minggu. Minggu pertama untuk meninjau pencapaian di bidang 1, minggu kedua untuk meninjau bidang 2 dan seterusnya.

Pembentukan tim gugus tugas yang didasarkan Keputusan Walikota Bekasi Nomor 463/kep.62-DPPPA/II/2019 tentang Tim Gugus Tugas Kota Layak Anak Kota Bekasi Tahun 2019 semakin memperjelas batasan tugas dan fungsi setiap satuan kerja perangkat daerah dimana mereka harus bertanggungjawab sebagai agen pelaksana pemenuhan hak-hak terhadap anak.

SMK Negeri 6 sebagai pelaksana, juga telah menunjukan adanya kelancaran rutinitas fungsi, yang mana dalam pemberian hukuman tidak adalagi hukuman fisik dan kekerasan. Hal ini menjadi bukti bahwa sekolah sebagai agen pelaksana telah paham betul mengenai apa itu sekolah ramah anak. Hukuman melalui pendekatan persuasif, yang mana diakui siswa SMK Negeri 6 Kota Bekasi semakin dekat dan hormat dengan pengajar mereka, sehingga hubungan antara siswa dengan guru di sana sangat akrab, bahkan bisa makan siang bersama dalam satu meja.

Rutinitas lain juga terlihat dari kawasan tanpa rokok yang ada di lingkungan SMK Negeri 6 Kota Bekasi tidak ada satupun yang merokok termasuk security, kebersihan ataupun penjual makanan. Hal ini juga menjadi fungsi sekolah untuk memberikan contoh yang baik dan juga menjadi poin penilaian dalam sekolah ramah anak. Lalu, dana kawan juga dilakukan sebagai rutinitas dalam menjalankan fungsi mereka dimana dana kawan ini dikelola oleh siswa untuk membantu beberapa teman-teman mereka yang kurang mampu, hal ini sudah sesuai dengan aturan tambahan dari walikota bekasi untuk setidaknya menyediakan $20 \%$ pendidikan bagi warga kurang mampu. Sehingga dalam menjalankan sekolah ramah anak tidak ada hambatan berarti, karena setiap masyarakat sekolah mengerti apa itu sekolah ramah anak. 
Setiap lembaga yang terkait dengan program kota layak anak, telah mengetahui secara jelas bagaimana tugas dan fungsi mereka sehingga dapat berjalan berdampingan, tidak terdapat tumpang tindih, dibuktikan dengan setiap instansi terkait memiliki jadwal tersendiri untuk melakukan fungsi mereka dengan tanpa hambatan berarti, pembentukan tim gugus tugas yang didasarkan Keputusan Walikota Bekasi Nomor 463/kep.62-DPPPA/II/2019 tentang Tim Gugus Tugas Kota Layak Anak Kota Bekasi Tahun 2019 semakin memperjelas batasan tugas dan fungsi setiap satuan kerja perangkat daerah dimana mereka harus bertanggungjawab sebagai agen pelaksana pemenuhan hak-hak terhadap anak.

Begitupun lancarnya rutinitas fungsi di sekolah ramah anak, yang mana hal yang harus digarisbawahi adalah SRA memanusiakan manusia, sehingga dalam pelaksanaanya juga warga masyarakat SMK Negeri 6 Kota Bekasi berlaku sebagaimana mestinya, guru sebagai orang tua tentu menampilkan contoh yang baik kepada anak seperti tidak merokok ataupun membentak, sehingga berimbas pada karakter siswa. Sehingga rutinitas tersebut selalu berulang sehingga diharapkan akan menjadi suatu kebiasaan. Sehingga hal ini menunjukan adanya kelancaran rutinitas fungsi masing-masing, baik itu dinas ataupun sekolah.

Oleh karenanya, dari indikator kedua, menunjukkan bahwa implementasi kebijakan berhasil sebab maisng-masing lembaga mengetahui dimana tugas dan bagaimana harus bersikap sesuai dengan aturan dan fungsi mereka masing-masing

Terwujudnya kinerja dan dampak yang diinginkan, keberhasilan implementasi suatu kebijakan terlihat dari kinerja dan dampak yang dirasakan. Menurut Ripley dan Franklin bahwa terwujudnya kinerja mengarah kepada proses pengimplementasian kebijakan dengan pencapaian diukur dari kecepatan waktu. Sedangkan dampak tersebut diukur dari pencapaian implementasi dalam waktu yang panjang.

Kota Bekasi melalui DP3A telah menunjukan kinerja sehingga dalam empat tahun telah mencapai predikat Nindya untuk Kota Layak Anak, yang mana waktu cepat untuk mencapai hal tersebut karena adanya aturan yang bersifat memaksa sehingga dari berbagai bidang berusaha untuk melakukan pemenuhan terhadap hak-hak dasar anak. Hal ini merupakan pencapaian yang mengukur jika kinerja yang baik telah dilakukan oleh Dinas Pemberdayaan Perempuan dan Perlindungan Anak Kota Bekasi yang secara bersama-sama dengan dinas lainnya guna melakukan pemenuhan terhadap hak-hak anak sehingga Kota Bekasi meraih predikat Nindya. Untuk dampak yang diinginkan tentu saja terjadinya penurunan kasus terhadap anak baik secara regional maupun nasional.

Sementara untuk sekolah-sekolah yang ramah anak terutama SMK Negeri 6 Kota Bekasi, pencapaian kinerja dalam waktu cepat dengan keikutsertaan mendukung program pemerintah selang setahun program tersebut digulirkan ke sekolah-sekolah yang ada di Kota Bekasi, sehingga menunjukkan adanya keseriusan dari elemen masyarakat untuk memperhatikan hak-hak anak dan melakukan perlindungan serta menjamin tumbuh kembang mereka. Kemudian, tingkat kehadiran siswa didik meningkat, yang menunjukkan bahwa terjadi hubungan baik murid dengan gurunya. 
Tentu saja, dampak yang diinginkan bahwa sekolah akan menjadi tempat yang aman nyaman bagi tumbuh kembang anak, menjadi ruang ekspresi sehingga fungsi lembaga pendidikan sebagai salah satu agen yang membentuk karakter anak dapat tercapai.

\section{Kesimpulan}

Implementasi telah berjalan dengan baik, sebab untuk mendapatkan kenaikan predikat harus terus terjadi penambahan atau pemutakhiran di berbagai bidang dalam pemenuhan hakhak anak. Dengan adanya SRA tentu setidaknya sekolah menjadi salah satu tempat aman baik tumbuh kembang peserta didik untuk mencetak generasi muda yang unggul berkualitas. Dengan adanya sekolah ramah anak juga sebagai bentuk capaian terhadap realisasi negara dalam menjamin hak anak sebagai salah satu hak asasi manusia. Dilihat dari dimensi kepatuhan, setiap elemen yang berkaitan selalu mengacu kepada peraturan yang menjadi landasan dalam bergerak melaksanakan penerapan sekolah ramah anak. Sedangkan untuk dimensi kelancaran fungsi, masing-masing lembaga mengetahui bagaimana tugas dan bagaimana harus bersikap sesuai dengan aturan, sehingga nantinya akan menjadi pembiasaan bagi individu yang menjalankan. Terakhir, dari dimensi terwujudnya kinerja dilihat dari kehadiran dan keaktifan siswa serta dampak yang diinginkan adalah penurunan kasus kekerasan anak juga menjadikan sekolah sebagai tempat aman bagi tumbuh kembang peserta didik juga sebagai agen pembentuk penerus bangsa.

\section{Daftar Pustaka}

Davit Setiyawan. (2015). KPAl: Pelaku Kekerasan Terhadap Anak Tiap Tahun Meningkat. https://www.kpai.go.id/publikasi/kpai-pelaku-kekerasan-terhadap-anak-tiap-tahunmeningkat

Hamid, P. (2017). Kabupaten Kota Layak Anak. Jurnal Kriminologi Indonesia, 13(1), 39-40. http://journal.ui.ac.id/index.php/jki/article/viewFile/9044/67545914

Ilosa, A. (2020). Analisis Pelaksanaan Program Kota Layak Anak (KLA) dalam Memenuhi Hak Sipil dan Kebebasan Anak di Kota Pekanbaru. Jurnal Mahasiswa IImu Administrasi Publik, 2, 87-101. http://jmiap.ppj.unp.ac.id/index.php/jmiap/article/view/118/66

Joga, N. (2019). Keluarga dan Kota Layak Anak. Investor.Id. https://investor.id/opinion/192027/keluarga-dan-kota-layak-anak

KLA. (2017). Kota Ramah Anak. KLA. https://www.kla.id/kota-ramah-anak/

Koesnan, R. A. (2005). Susunan Pidana dalam Negara Sosialis Indonesia. Sumur.

KPPA. (2007). Fenomena Tindak Kekerasan terhadap Anak dan Perempuan. Badan Pusat Statistik.

Moleong, L. J. (2008). Metode Penelitian Kualitatif. PT. Remaja Rosdakarya.

Monks, F. J., A.M.P Knoers, \& Haditono, S. R. (2006). Psikologi Perkembangan: Pengantar dala Berbagai Bagaiannya. Gadjah Mada University Press.

Peraturan Daerah Kota Bekasi Nomor 13 Tahun 2017 tentang Kota Layak Anak, (2017). 
Peraturan Menteri Pemberdayaan Perempuan dan Pelindungan Anak Nomor 11 Tahun 2011 tentang Kabupaten atau Kota Layak Anak, (2011).

Peraturan Pemerintah Republik Indonesia Nomor 18 Tahun 2016 tentang Perangkat Daerah, (2016).

Putra, P. M. S. (2015). Komnas PA: 2015, Kekerasan Anak Tertinggi Selama 5 Tahun Terakhir.

Liputan 6. https://www.liputan6.com/news/read/2396014/komnas-pa-2015-kekerasananak-tertinggi-selama-5-tahun-terakhir

Subekti, \& Tjitrosudibio. (2002). Kitab Undang-Undang Hukum Perdata. PT. Pradnya Paramita.

Sugiono, P. D. (2016). Metode Penelitian Kuantitatif, Kualitatif dan R\&D. CV. Alfabeta.

Undang-Undang Nomor 23 Tahun 2002 tentang Perlindungan Anak, (2002).

Undang-Undang Republik Indonesia Nomor 20 Tahun 2003, (2003).

Undang-Undang Nomor 7 Tahun 2007 tentang Rencana Pembangunan Jangka Panjang Nasional, (2007).

Undang-Undang Nomor 23 Tahun 2014 tentang Pemerintah Daerah, (2014).

Undang-Undang Nomor 2 Tahun 2015 Tentang Rencana Pembangunan Jangka Menengah, (2015). 